\title{
TOXICITY OF TWO HOUSEHOLD LIQUID SOAPS ON POECILIA RETICULATA PETERS, 1859
}

\author{
LAWAL, M. O. ${ }^{1 *}$; SAMUEL, O. B. ${ }^{1}$; MOGEKWU, T. 0. ${ }^{1} \&$ BOLAJI, D. A. ${ }^{2}$ \\ 1 - Department of Marine Sciences, University of Lagos, Akoka-Yaba, Lagos, Nigeria. \\ 2 - Department of Fisheries, Nigerian Institute for Oceanography and Marine Research, Victoria \\ Island, Lagos, Nigeria. \\ *Corresponding author: mlawal@unilag.edu.ng
}

\begin{abstract}
Lawal, M. O.; Samuel, O. B.; Mogekwu, T. O. \& Bolaji, D. A. (2013) Toxicity of Two Household Liquid Soaps on Poecilia reticulata Peters, 1859. Braz. J. Aquat. Sci. Technol. 17(1):35-41. elSSN 1983-9057. DOI:10.14210/bjast.v17. n1.p35-41. The relative acute toxicity and sub-lethal effects of two surfactants; Faab liquid soap (FLS) and Morning Fresh liquid soap (MFLS) were evaluated for the Poecilia reticulata in laboratory bioassays. The acute toxicity was evaluated for $96 \mathrm{~h}$ while the sub-lethal effects of the two surfactants on the biochemical parameters of $P$. reticulata were investigated for a 6 - day exposure period. The derived toxicity indices showed that the FLS $\left(96 \mathrm{hLC}{ }_{50}=0.062 \mathrm{ml} / \mathrm{L}\right)$ was 1.37 times more toxic than the MFLS $\left(96 \mathrm{hLC}{ }_{50}=0.085 \mathrm{ml} / \mathrm{L}\right)$ against $P$. reticulata. Analysis of variance (ANOVA) showed significant difference $(p<0.05)$ in the quantal response of $P$. reticulata to different concentrations of FLS and MFLS at 24, 48, 72 and $96 \mathrm{~h}$ of exposure. The mean tissue protein, triglyceride, glucose and cholesterol ranged from (21.04 - 48.54 and 18.06 - 58.54mg/dl), ( $87.43-154.95$ and $85.63-144.28 \mathrm{mg} / \mathrm{dl}),(33.95-55.03$ and $32.76-53.15 \mathrm{mg} / \mathrm{dl})$ and $(37.30-65.38$ and $37.12-58.11 \mathrm{mg} / \mathrm{dl})$ for FLS and MFLS respectively. ANOVA showed significant difference $(p<0.05)$ in the biochemical response of $P$. reticulata to FLS and MFLS. The implications of these findings are highlighted.
\end{abstract}

Keywords: Toxicity, biochemical, surfactants, fish.

\section{INTRODUCTION}

The ever increasing need to keep house-hold and environment clean in order to prevent outbreak of diseases and allergies has led to regular and increased use of domestic liquid soaps (surfactants) which are based on surface active chemical agents. These substances, when dissolved in water, produce a solution that has the ability to remove dirt from surfaces such as textiles and dishes, acting as well as oil dispersant (Liwarska-Bizukojc et al., 2005). Surfactants are not only used as detergents, they have been successfully employed to enhance the efficacy of the active ingredient in pharmaceutical and agriculture formulations, in cosmetics and other industrial processes (Cserha'ti et al., 2002). However, the indiscriminate discharge of surfactants and their components into the aquatic and terrestrial environments, primarily as a result of their commercial and household use has resulted in pollution of water bodies (Beey, 2001).

According to Madsen et al. (2001) dish washer detergents are capable of destroying the external mucus layers that protect the fish from bacteria and parasite infection. In addition, exposure to low-levels of some surfactants can cause disruption of endocrine functions in fish, such as reproduction (Barber et al., 2007). Sub-lethal concentrations of an anionic detergent were reported to have damage the catfish barbell taste buds (Zeni \& Caligiuri, 1992; Zeni et al., 1995). Also the anionic surfactants that belong to alkyl sulphates (AS), linear alkylbenzene sulphonates (LAS) and alkylpolyoxyethylene sulphates (AES) were harmful to aquatic organisms (Physa acuta, Artemia salina and Raphidocelis subcapitata) at concentration range of 10 and $100 \mathrm{mg} / \mathrm{L}$ (Liwarska-Bizukojc et al., 2005). Furthermore, documented studies on biochemical changes in fish exposed to toxicants include; blood protein (Omoniyi et al., 2002; Martinez et al., 2004), triglyceride and cholesterol (Abalaka et al., 2011; Maruf Iftekhar, et al., 2006; Omitoyin, 2007) and tissue glucose (Ajani et al., 2007).

Fish have often been considered as the sentinel organism for health of aquatic environment and respond to chemicals in a manner similar to that of higher vertebrates (Beey, 2001; Barbieri, 2007). Guppy, Poecilia reticulata Peters, 1859, occupies a wide range of aquatic habitats, such as ponds, weedy ditches, canals and tolerates a wide range of environmental conditions. They are very sensitive, easy to maintain in the laboratory and very prolific (Lawal, 2010). Earlier similar studies on $P$. reticulata include its use as a test species for a wide spectrum organophosphorus insecticide (Mahmut et al., 2005), spent lubrication oil and laundry detergent (Otitoloju, 2006) and pirimiphosmethyl (Lawal \& Samuel, 2010).

In spite of the fact that many toxicity data for surfactants have been provided so far, the research of their toxicity is still regarded as relatively limited (Liwarska-Bizukojc et al., 2005) due to their extensive use in an emerging economy such as Nigeria. 
The present study evaluated the acute toxicity and biochemical responses of $P$. reticulata to 'Faab' and 'Morning fresh' liquid soaps.

\section{MATERIALS AND METHODS}

\section{Test Animal and Acclimatization}

Guppy of size range 2.50 to $3.40 \mathrm{~cm}$ used for this study were obtained from a drainage canal at the entrance of the University of Lagos, Akoka, Lagos, Nigeria. They were caught with a scoop net of mesh size $2.0 \mathrm{~mm}$ and carried to the laboratory in a plastic bucket half filled with water from source. The collection was made in the morning and evening to reduce stress on the organism. They were kept in holding tanks (80 $\times 45 \times 30 \mathrm{~cm}^{3}$ ) one quarter filled with dechlorinated tap water and allowed to acclimatize to laboratory conditions $(27.0 \pm 0.60 \mathrm{C}, \mathrm{pH}=7.0)$ for two weeks before using them in bioassays. Fish were fed with floating pellets at $10 \%$ of their body weight. Unconsumed feed and faeces were removed and water replenished twice a week to prevent accumulation of toxic waste metabolites.

\section{Test Chemicals}

'Faab' liquid soap is a stain remover and used frequently in the kitchen. This product was manufactured by Washing Up Nigeria Limited. Ingredients that were used in its production are anionic surfactants, perfume, preservative and stabilizer. Similarly, 'Morning fresh' liquid soap removes grease and stains and used more frequently in the kitchen. It was manufactured by PZ Industries Nigeria PLC. Ingredients used in its manufacture are anionic surfactants, hydro-tropes, salts, perfume, and preservatives.

\section{Physico-chemical Parameters of the Test Media}

Physico-chemical parameters such as dissolved oxygen (DO), $\mathrm{pH}$, and temperature of the test media were measured before and during the experimental period. The $\mathrm{pH}$ and temperature was measured using Hanna instrument (Model H1991301). The dissolved oxygen was determined using a Jenway DO meter (Model 9071).

\section{Acute Toxicity Test}

A static bioassay technique (static renewal) was adopted for all the toxicity tests (FAO, 1987). Depending on the test concentrations, a given volume of water from the test organism environment was measured into bioassay glass tank $\left(45 \times 30 \times 30 \mathrm{~cm}^{3}\right)$ and a predetermined volume of Faab liquid soap or Morning fresh liquid soap was added to the water to make up to $1000 \mathrm{ml}$, to achieve the desired concentration.
Ten (10) active fish were introduced into the test medium containing either Faab or Morning fresh liquid soap. Fish used for the test were not fed a day preceding the test and throughout the duration of the test. Each treatment was replicated thrice, given a total of 30 guppies per treatment, including untreated media (control). The concentrations of test chemicals were as follow:

- Faab: 0.05, 0.06, 0.07, 0.08, 0.09mIL and control

- Morning fresh: 0.082, 0.084, 0.086, 0.088, $0.090 \mathrm{mIL}$ and control

Mortality assessment was carried out every 24 hours over a 96-hour experimental period. Fish were assumed dead when there was no body or operculum movement, even when probed with a glass rod. Dead animals were removed and recorded.

\section{Biochemical Assay Techniques}

Exposure of fish to sub-lethal concentrations of 1/10th, 1/50th and 1/100th of $96 \mathrm{hrLC}_{50}$ values of the test compounds for a duration of 6 days were determined as follow:

- Faab: 15.5, 31.0, and $155.0 \mathrm{ml} / \mathrm{L}$ and control

- Morning fresh: 21.25, 42.50, and 212.50ml/L and control

At day 2, 4 and 6 , six live $P$. reticulata were randomly selected per treatment including the control for the Faab and Morning Fresh liquid soaps. The test organisms were weighed to determine their individual weight. Animals were anaesthetized with MS-222 (Methane sulfonate) at $140 \mathrm{mg} / \mathrm{L}$ for decreased respiration and complete loss of responsiveness (Ross and Ross, 2008) before their whole tissue (flesh) was used. The samples from test animals were homogenized in phosphate buffer (50mM, pH 7.0). The tissue homogenate were analyzed with Human $®$ kits for triglyceride, cholesterol, glucose and protein using GPO-PAP, CHOD-PAP, GOD-PAP and Biuret methods respectively (Josephson \& Gyllensward, 1957; Teuscher \& Richterich, 1971; Schettler \& Nussel, 1975).

\section{Statistical Analysis}

The quantal response (mortality) data were analyzed by probit analysis after Finney (1971). The indices of toxicity measurement derived from the analysis were;

- $\mathrm{LC}_{50}=$ the concentration that kills $50 \%$ of the population.

- TF (Toxicity factor) for relative potency measurements.

One-way analysis of variance (ANOVA) and Student Newman-Keul's, (SNK) tests were used to test for significant difference ( $5 \%$ level) in the mean mortality response of $P$. reticulata to different concentrations of Faab and Morning fresh liquid soaps at 24, 48, 72 
and 96 hours of exposure. The significant differences in biochemical assay data were analysed using ANOVA and Duncan multiple range test (DMRT) at $P=0.05$. Analysis was performed using SPSS 10.0 for Windows.

\section{RESULTS}

Physico-chemical conditions of the test media during the experimental period were fairly constant. The temperature ranged between 25.0 and $27.0^{\circ} \mathrm{C}, \mathrm{pH}$ ranged between 7.0 and 7.8 while dissolved oxygen ranged from 5.0 to $6.8 \mathrm{mg} / \mathrm{L}$ over the $96 \mathrm{~h}$ acute toxicity and sub-lethal evaluations.

\section{Relative Toxicity of Faab and Morning Fresh Liquid Soaps on $P$. reticulata}

The results of the acute toxicity of Faab and Morning fresh liquid soaps on $P$. reticulata at $24,48,72$ and $96 \mathrm{~h}$ of exposure are shown in Table 1 . The analysis of concentration-mortality data of Faab liquid soap (FLS) when tested against $P$. reticulata revealed that the derived toxicity indices $\left(\mathrm{LC}_{50}\right)$ ranged from 0.062 $\left(96 \mathrm{hLC}_{50}\right)$ to $0.079 \mathrm{ml} / \mathrm{L}\left(24 \mathrm{hLC}_{50}\right)$, while for Morning fresh liquid soap (MFLS), the $\mathrm{LC}_{50}$ ranged from 0.085 $\left(96 \mathrm{hLC}_{50}\right)$ to $0.089 \mathrm{ml} / \mathrm{L}\left(24 \mathrm{hLC}_{50}\right)$. On the basis of computed toxicity factor (TF) using $96 \mathrm{hLC}_{50}$, the FLS was found to be 1.37 times more toxic on $P$. reticulata than the MFLS (Table 1).

An analysis of variance (ANOVA) showed that there was significant difference $(p<0.05)$ in the quantal response (mortality) of $P$. reticulata to different treatments (concentrations) of Faab and Morning fresh liquid soaps at 24, 48, 72 and $96 \mathrm{~h}$ of exposure. Further analysis using Student Newman Keul's (SNK) test ( $p=$ $0.05)$ revealed that the percentage mortality response of $P$. reticulata to $0.09 \mathrm{ml} / \mathrm{L}$ of $\mathrm{FLS}$ at $24,48,72$ and $96 \mathrm{~h}$ of exposure was significantly different $(p<0.05)$ from its response to all other concentrations (Table 2). However, at $72 \mathrm{~h}$ of exposure no significant difference ( $>0.05$ ) was observed in the quantal response of $P$. reticulata exposed to 0.0 (control) and $0.05 \mathrm{ml} / \mathrm{L}$ of FLS, while at $96 \mathrm{~h}$ of exposure no significant difference ( $p>0.05)$ was observed in the quantal response of $P$. reticulata exposed to 0.07 and $0.08 \mathrm{ml} / \mathrm{L}$ of FLS (Table 2). Similarly, SNK showed that the percentage mortality response of guppies to $0.090 \mathrm{ml} / \mathrm{L}$ of MFLS at $24,48,72$ and $96 \mathrm{~h}$ of exposure was significantly different $(p<0.05)$ from its response to all other concentrations (Table 3 ). However, at $24 \mathrm{~h}$ of exposure no significant difference $(p>0.05)$ was observed in the quantal response of guppies exposed to 0.0 and $0.082 \mathrm{ml} / \mathrm{L}$ of MFLS while at $72 \mathrm{~h}$ of exposure no significant difference $(p>0.05)$ was observed in the quantal response of guppies exposed to 0.082 and $0.084 \mathrm{ml} / \mathrm{L}$ of MFLS (Table 3).

No adverse behavioral changes or mortality was observed in the control fish throughout the experimental period. However, erratic swimming, restlessness and impaired balance were observed in test animals exposed to surfactants before their eventual death.

\section{Sub-lethal effects of Faab and Morning Fresh Liquid Soaps on Tissue Chemistry of $P$. reticulata}

The results of the biochemical changes in tissue protein, triglyceride, glucose and cholesterol observed in $P$. reticulata exposed to different sub-lethal concentrations of Faab and Morning fresh liquid soaps are shown in Tables 4 and 5 respectively.

The lowest value $(21.04 \pm 0.71 \mathrm{mg} / \mathrm{dl})$ of mean tissue protein was recorded in organism exposed to $31.0 \mathrm{ml} / \mathrm{L}$ on day 6 while the highest value $(39.29 \pm 2.85 \mathrm{mg} / \mathrm{dl})$ was recorded in organism exposed to $15.5 \mathrm{ml} / \mathrm{L}$ on day 2 . The values of mean tissue protein in the guppy decreased with increased days across treatments with FLS (Table 4). There was significant difference $(p<0.05)$ in the mean tissue protein of test organisms exposed to different concentrations of FLS (Table 4). Duncan Multiple Range Test (DMRT) showed significant difference $(p<0.05)$ in the mean tissue protein of $P$. reticulata across treatments and days. However, there was no significant difference $(p$ $>0.05)$ in the mean tissue protein values of treatments

Table 1 - Relative Toxicity of Faab and Morning Fresh liquid soaps on P. reticulata.

\begin{tabular}{lcclc}
\hline \hline Exposure Time $(\mathbf{h})$ & $\mathbf{L C}_{50}(\mathbf{9 5 \%} \mathbf{C L})(\mathbf{m l} / \mathbf{L})$ & Slope \pm SE & Probit line equation & TF \\
\hline Faab & & & & \\
24 & $0.079(0.075-0.084)$ & $10.53 \pm 1.70$ & $16.62+10.53 \mathrm{x}$ & \\
48 & $0.074(0.070-0.080)$ & $8.48 \pm 1.40$ & $14.59+8.48 \mathrm{x}$ & \\
72 & $0.066(0.062-0.070)$ & $10.14 \pm 1.46$ & $16.96+10.14 \mathrm{x}$ & \\
96 & $0.062(0.058-0.066)$ & $9.90 \pm 1.50$ & $16.93+9.89 \mathrm{x}$ & 1.3 \\
Morning Fresh & & & \\
24 & $0.089(0.088-0.902)$ & $58.37 \pm 10.24$ & $66.37+58.37 \mathrm{x}$ & \\
48 & $0.088(0.087-0.090)$ & $46.92 \pm 8.56$ & $54.56+46.92 \mathrm{x}$ & \\
72 & $0.087(0.086-0.088)$ & $54.49 \pm 8.66$ & $62.90+54.49 \mathrm{x}$ & \\
96 & $0.085(0.084-0.086)$ & $64.13 \pm 9.44$ & $73.66+64.13 \mathrm{x}$ & 1.03 \\
\hline \hline
\end{tabular}

$\mathrm{CL}=$ Confidence limit, $\mathrm{SE}=$ Standard error, $\mathrm{TF}=$ Toxicity factor $=96 \mathrm{hLC}_{50}$ value of Faab and Morning Fresh $/ 96 \mathrm{hLC}{ }_{50}$. 
Table 2 - Percentage (\%) mortality of $P$. reticulata exposed to different concentrations of Faab liquid soap for 96 hours.

\begin{tabular}{cccccc}
\hline \hline Concentration & No. of tested & \multicolumn{4}{c}{ Percentage Mortality/Time } \\
(mIlL) & organisms & $\mathbf{2 4 h}$ & $\mathbf{4 8 h}$ & $\mathbf{7 2 h}$ & $\mathbf{9 6 h}$ \\
\hline Control (0) & 30 & $0.00^{\mathrm{a}}$ & $0.00^{\mathrm{a}}$ & $0.00^{\mathrm{a}}$ & $0.00^{\mathrm{a}}$ \\
0.05 & 30 & $33.3^{\mathrm{ab}}$ & $10.0^{\mathrm{b}}$ & $10.0^{\mathrm{a}}$ & $16.3^{\mathrm{b}}$ \\
0.06 & 30 & $10.0^{\mathrm{b}}$ & $20.0^{\mathrm{c}}$ & $26.7^{\mathrm{b}}$ & $40.0^{\mathrm{c}}$ \\
0.07 & 30 & $26.7^{\mathrm{c}}$ & $40.0^{\mathrm{d}}$ & $73.3^{\mathrm{c}}$ & $76.6^{\mathrm{d}}$ \\
0.08 & 30 & $50.0^{\mathrm{d}}$ & $60.0^{\mathrm{e}}$ & $80.0^{\mathrm{cd}}$ & $83.3^{\mathrm{d}}$ \\
0.09 & 30 & $76.7^{\mathrm{e}}$ & $80.0^{\mathrm{f}}$ & $86.7^{\mathrm{d}}$ & $93.3^{\mathrm{e}}$ \\
\hline \hline
\end{tabular}

Means with the same superscript letter(s) in a column are not significantly different in the SNK test at $\mathrm{P}=0.05$

0.0 (control) and $155.0 \mathrm{ml} / \mathrm{L}$ on day 2 . Similarly, there was no significant difference $(p>0.05)$ in the mean tissue protein values of treatments 0.0 (control) and $15.5 \mathrm{ml} / \mathrm{L}$ on day 4 and also between treatments 15.5 and $155.0 \mathrm{ml} / \mathrm{L}$ on day 6 (Table 4 ).

Also, the lowest value $(87.43 \pm 5.23 \mathrm{mg} / \mathrm{dl})$ of the mean tissue triglyceride was recorded in organism exposed to $0.0 \mathrm{ml} / \mathrm{L}$ (control) on day 6 while the highest value $(154.95 \pm 3.96 \mathrm{mg} / \mathrm{dl})$ was recorded in organism exposed to $31.0 \mathrm{ml} / \mathrm{L}$ on day 2 . The values of mean tissue triglyceride in guppy decreased with increased days across treatments with FLS. Significant difference $(p<0.05)$ was recorded in the mean tissue triglyceride of test organisms exposed to different concentrations of FLS. DMRT showed significant differences $(p<0.05)$ in the mean tissue triglyceride of $P$. reticulata across treatments and days. However, there was no significant difference $(p>0.05)$ in the mean tissue triglyceride values of treatments 0.0 (control) and $15.5 \mathrm{ml} / \mathrm{L}$ on days 2, 4 and 6 . Similarly, no significant difference $(p$ $>0.05$ ) was observed in the mean tissue triglyceride values of treatments 31.0 and $155.0 \mathrm{ml} / \mathrm{L}$ on days 2 and 4 (Table 4).

Furthermore, the lowest value $(33.95 \pm 0.98 \mathrm{mg} /$ dl) of the mean tissue glucose was recorded in organisms exposed to $31.0 \mathrm{ml} / \mathrm{L}$ on day 6 while the highest value $(55.03 \pm 2.18 \mathrm{mg} / \mathrm{dl})$ was recorded in organisms exposed to $15.5 \mathrm{ml} / \mathrm{L}$ on day 2 . The values of mean tissue glucose in guppy decreased with increased days across treatments with FLS. Significant difference ( $p$ $<0.05)$ was recorded in the mean tissue glucose of test organisms exposed to different concentrations of FLS (Table 4). DMRT showed significant difference $(p<$ 0.05 ) in the mean tissue glucose of $P$. reticulata across treatments and days. However, on day 2, no significant difference $(p>0.05)$ was recorded in the mean tissue glucose values between treatments 0.0 (control) and $15.5 \mathrm{ml} / \mathrm{L}$ and treatments 31.0 and $155.0 \mathrm{ml} / \mathrm{L}$. Similarly, on day 6 no significant difference $(p>0.05)$ was recorded in the mean tissue glucose values between treatments 0.0 (control) and $155.0 \mathrm{ml} / \mathrm{L}$ and treatments 15.5 and $31.0 \mathrm{ml} / \mathrm{L}$ (Table 4 ).

The lowest value $(37.30 \pm 0.30 \mathrm{mg} / \mathrm{dl})$ and the highest value $(65.38 \pm 4.60 \mathrm{mg} / \mathrm{dl})$ of the mean tissue
Table 3 - Percentage (\%) mortality of $P$. reticulata exposed to different concentrations of Morning Fresh liquid soap for 96 hours.

\begin{tabular}{cccccc}
\hline \hline $\begin{array}{c}\text { Concentration } \\
\text { (mIlL) }\end{array}$ & No. of tested & \multicolumn{4}{c}{ Percentage Mortality/Time } \\
organisms & $\mathbf{2 4 h}$ & $\mathbf{4 8 h}$ & $\mathbf{7 2 h}$ & $\mathbf{9 6 h}$ \\
\hline Control (0) & 30 & $0.00^{\mathrm{a}}$ & $0.00^{\mathrm{a}}$ & $0.00^{\mathrm{a}}$ & $0.00^{\mathrm{a}}$ \\
0.082 & 30 & $3.3^{\mathrm{a}}$ & $10.0^{\mathrm{ab}}$ & $13.0^{\mathrm{b}}$ & $20.0^{\mathrm{b}}$ \\
0.084 & 30 & $10.0^{\mathrm{ab}}$ & $20.0^{\mathrm{bc}}$ & $20.0^{\mathrm{b}}$ & $30.0^{\mathrm{c}}$ \\
0.086 & 30 & $16.7^{\mathrm{b}}$ & $26.6^{\mathrm{c}}$ & $40.0^{\mathrm{c}}$ & $66.7^{\mathrm{d}}$ \\
0.088 & 30 & $33.3^{\mathrm{c}}$ & $50.0^{\mathrm{d}}$ & $66.7^{\mathrm{d}}$ & $80.0^{\mathrm{e}}$ \\
0.090 & 30 & $70.0^{\mathrm{d}}$ & $73.3^{\mathrm{e}}$ & $83.3^{\mathrm{e}}$ & $96.7^{\mathrm{f}}$ \\
\hline \hline
\end{tabular}

Means with the same superscript letter(s) in a column are not significantly different in the SNK test at $\mathrm{P}=0.05$

cholesterol were recorded in organisms exposed to $31.0 \mathrm{ml} / \mathrm{L}$ on days 6 and 4 respectively. In addition, significant difference $(p<0.05)$ was observed between the control group and other treatments in the mean tissue cholesterol of test organisms exposed to FLS on days 2,4 and 6. DMRT showed no significant difference $(p$ $<0.05)$ in the mean tissue cholesterol of $P$. reticulata amongst treatments $15.5,31.0$ and $155.0 \mathrm{ml} / \mathrm{L}$ (Table 4).

The lowest $(18.06 \pm 0.55 \mathrm{mg} / \mathrm{dl})$ and highest $(58.54 \pm 4.04 \mathrm{mg} / \mathrm{dl})$ values of the mean tissue protein of $P$. reticulata were recorded in organisms exposed to $21.25 \mathrm{ml} / \mathrm{L}$ on days 6 and 2 respectively. The values of mean tissue protein in guppy decreased with increased days across treatments with MFLS (Table 5). However, no significant difference $(p>0.05)$ in the mean tissue protein of test organisms exposed to different concentrations of MFLS on day 4. On day 2, DMRT showed significant difference $(p<0.05)$ in the mean tissue protein of $P$. reticulata exposed to $21.25 \mathrm{ml} / \mathrm{L}$ and other treatments. Similarly, on day 6, DMRT showed significant difference $(p<0.05)$ in the mean tissue protein of $P$. reticulata exposed to $212.5 \mathrm{ml} / \mathrm{L}$ and other treatments (Table 5).

The lowest value $(85.63 \pm 7.85 \mathrm{mg} / \mathrm{dl})$ of the mean tissue triglyceride was recorded in organism exposed to $21.25 \mathrm{ml} / \mathrm{L}$ on day 6 while the highest value $(144.28 \pm 6.33 \mathrm{mg} / \mathrm{dl})$ was recorded in organism exposed to $212.50 \mathrm{ml} / \mathrm{L}$ on day 2 . The values of mean tissue triglyceride in guppy decreased with increased days across treatments with MFLS. There was significant difference $(p<0.05)$ in the mean tissue triglyceride of test organisms exposed to different concentrations of MFLS. DMRT showed significant differences $(p<0.05)$ in the mean tissue triglyceride of $P$. reticulata across treatments and days. However, there was no significant difference $(p>0.05)$ in the mean tissue triglyceride values of treatments 0.0 (control) and $21.25 \mathrm{ml} / \mathrm{L}$ on days 2, 4 and 6 . Similarly, no significant difference $(p$ $>0.05$ ) was observed in the mean tissue triglyceride values of treatments 42.50 and $212.50 \mathrm{ml} / \mathrm{L}$ on days 2 and 4 (Table 5).

The lowest value $(32.76 \pm 1.29 \mathrm{mg} / \mathrm{dl})$ and the highest value $(53.15 \pm 1.67 \mathrm{mg} / \mathrm{dl})$ of mean tissue glucose were recorded in organisms exposed to $21.25 \mathrm{ml} / \mathrm{L}$ 
Table 4 - Mean protein, triglyceride, glucose and cholesterol contents in the tissue of $P$. reticulata exposed to sublethal concentrations of Faab liquid soap.

\begin{tabular}{cccc}
\hline \hline $\begin{array}{c}\text { Concentration } \\
\text { (ml/L) }\end{array}$ & \multicolumn{3}{c}{ Duration of treatment (Days) mg/dl } \\
\hline Protein & & $\mathbf{4}$ & $\mathbf{6}$ \\
Control (0) & $30.81 \pm 1.00^{\mathrm{a}}$ & $24.78 \pm 1.10^{\mathrm{a}}$ & $25.79 \pm 2.20^{\mathrm{b}}$ \\
15.5 & $39.29 \pm 2.85^{\mathrm{ab}}$ & $24.69 \pm 1.65^{\mathrm{a}}$ & $23.32 \pm 0.53^{\mathrm{ab}}$ \\
31.0 & $48.54 \pm 5.44^{\mathrm{b}}$ & $30.78 \pm 0.77^{\mathrm{b}}$ & $21.04 \pm 0.71^{\mathrm{a}}$ \\
155.0 & $34.79 \pm 3.37^{\mathrm{a}}$ & $27.40 \pm 0.87^{\mathrm{ab}}$ & $24.86 \pm 1.34^{\mathrm{ab}}$ \\
& & & \\
Triglyceride & & & \\
Control (0) & $96.03 \pm 5.56^{\mathrm{a}}$ & $87.67 \pm 4.74^{\mathrm{a}}$ & $87.43 \pm 5.23^{\mathrm{a}}$ \\
15.5 & $115.62 \pm 9.08^{\mathrm{a}}$ & $101.94 \pm 7.92^{\mathrm{a}}$ & $99.65 \pm 8.72^{\mathrm{a}}$ \\
31.0 & $154.95 \pm 3.96^{\mathrm{b}}$ & $151.56 \pm 4.26^{\mathrm{b}}$ & $131.46 \pm 5.90^{\mathrm{b}}$ \\
155.0 & $142.96 \pm 9,56^{\mathrm{b}}$ & $136.38 \pm 9.17^{\mathrm{b}}$ & $109.58 \pm 8.26^{\mathrm{a}}$ \\
Glucose & & & \\
Control (0) & $47.33 \pm 0.90^{\mathrm{a}}$ & $37.18 \pm 0.30^{\mathrm{a}}$ & $43.31 \pm 1.04^{\mathrm{b}}$ \\
15.5 & $55.03 \pm 2.18^{\mathrm{c}}$ & $40.87 \pm 1.92^{\mathrm{a}}$ & $34.05 \pm 1.29^{\mathrm{a}}$ \\
31.0 & $54.34 \pm 0.65^{\mathrm{bc}}$ & $46.25 \pm 1.69^{\mathrm{b}}$ & $33.95 \pm 0.98^{\mathrm{a}}$ \\
155.0 & $49.65 \pm 2.11^{\mathrm{ab}}$ & $46.34 \pm 0.88^{\mathrm{b}}$ & $40.53 \pm 1.41^{\mathrm{b}}$ \\
Cholesterol & & & \\
Control (0) & $45.07 \pm 1.26^{\mathrm{a}}$ & $41.82 \pm 2.28^{\mathrm{a}}$ & $40.91 \pm 1.28^{\mathrm{a}}$ \\
15.5 & $54.21 \pm 1.58^{\mathrm{b}}$ & $54.58 \pm 4.16^{\mathrm{b}}$ & $43.41 \pm 1.77^{\mathrm{b}}$ \\
31.0 & $55.56 \pm 1.06^{\mathrm{b}}$ & $65.38 \pm 4.60^{\mathrm{b}}$ & $37.30 \pm 0.30^{\mathrm{b}}$ \\
155.0 & $53.26 \pm 2.73^{\mathrm{b}}$ & $62.93 \pm 322^{\mathrm{b}}$ & $43.18 \pm 2.71^{\mathrm{b}}$ \\
\hline \hline
\end{tabular}

Means with the same superscript letter(s) in a column are not significantly different in the DMRT test at $P=0.05$.

on days 6 and 2 respectively. The values of mean tissue glucose in guppy decreased with increased days across treatments with MFLS. There was significant difference $(p<0.05)$ in the mean tissue glucose of test organisms exposed to different concentrations of MFLS. DMRT showed significant difference $(p<$ 0.05 ) in the mean tissue glucose of $P$. reticulata across treatments and days. However, on days 2 and 6, no significant difference $(p>0.05)$ was recorded in the mean tissue glucose values between treatments 0.0 (control) and $212.50 \mathrm{ml} / \mathrm{L}$. Similarly, on days 2, 4 and 6 no significant difference $(p>0.05)$ was recorded in the mean tissue glucose values between treatments 21.25 and $42.50 \mathrm{ml} / \mathrm{L}$ (Table 5).

The lowest $(37.12 \pm 0.40 \mathrm{mg} / \mathrm{dl})$ and highest $(54.41 \pm 0.77 \mathrm{mg} / \mathrm{dl})$ values of the mean tissue cholesterol were recorded in organisms exposed to $42.50 \mathrm{ml} / \mathrm{L}$ on days 6 and 2 respectively. There was significant difference $(p<0.05)$ in the mean tissue cholesterol of test organisms exposed to different concentrations of MFLS. On day 2, DMRT did not show any significant difference $(p>0.05)$ in the mean tissue cholesterol values between treatments 0.0 (control) and $21.25 \mathrm{ml} / \mathrm{L}$ and treatments 42.50 and $212.50 \mathrm{ml} / \mathrm{L}$. Similarly, on day 6 no significant difference $(p>0.05)$ was recorded in the mean tissue cholesterol values between treatments 21.25 and $212.50 \mathrm{ml} / \mathrm{L}$ (Table 5).
Table 5 - Mean protein, triglyceride, glucose and cholesterol contents in the tissue of $P$. reticulata exposed to sublethal concentrations of Morning Fresh liquid soap.

\begin{tabular}{cccc}
\hline \hline $\begin{array}{c}\text { Concentration } \\
(\mathbf{m l} / \mathrm{L})\end{array}$ & \multicolumn{3}{c}{ Duration of treatment (Days) $\mathbf{m g} / \mathbf{d l}$} \\
$\mathbf{2}$ & $\mathbf{4}$ & $\mathbf{6}$ \\
\hline Protein & & & \\
Control (0) & $30.81 \pm 1.00^{\mathrm{a}}$ & $24.78 \pm 1.10^{\mathrm{a}}$ & $23.80 \pm 2.19^{\mathrm{a}}$ \\
21.25 & $58.54 \pm 4.04^{\mathrm{b}}$ & $26.25 \pm 0.84^{\mathrm{a}}$ & $18.06 \pm 0.55^{\mathrm{a}}$ \\
42.50 & $36.34 \pm 2.79^{\mathrm{a}}$ & $28.17 \pm 0.94^{\mathrm{a}}$ & $18.94 \pm 0.33^{\mathrm{a}}$ \\
212.50 & $31.29 \pm 1.74^{\mathrm{a}}$ & $28.39 \pm 1.81^{\mathrm{a}}$ & $22.40 \pm 1.87^{\mathrm{ab}}$ \\
& & & \\
Triglyceride & & & \\
Control (0) & $96.03 \pm 5.56^{\mathrm{a}}$ & $87.66 \pm 4.74^{\mathrm{a}}$ & $87.43 \pm 5.23^{\mathrm{a}}$ \\
21.25 & $103.42 \pm 4.47^{\mathrm{a}}$ & $100.14 \pm 6.41^{\mathrm{a}}$ & $85.63 \pm 7.85^{\mathrm{a}}$ \\
42.50 & $139.96 \pm 4.51^{\mathrm{b}}$ & $137.63 \pm 6.05^{\mathrm{b}}$ & $116.11 \pm 7.42^{\mathrm{b}}$ \\
212.50 & $144.28 \pm 6.33^{\mathrm{b}}$ & $139.78 \pm 7.59^{\mathrm{b}}$ & $99.86 \pm 4.11^{\mathrm{ab}}$ \\
& & & \\
Glucose & & & \\
Control (0) & $47.33 \pm 0.90^{\mathrm{a}}$ & $37.18 \pm 0.30^{\mathrm{a}}$ & $43.31 \pm 1.04^{\mathrm{b}}$ \\
21.25 & $53.15 \pm 1.67^{\mathrm{b}}$ & $39.70 \pm 1.67^{\mathrm{ab}}$ & $32.76 \pm 1.29^{\mathrm{a}}$ \\
42.50 & $52.95 \pm 1.43^{\mathrm{b}}$ & $40.99 \pm 1.32^{\mathrm{ab}}$ & $34.11 \pm 0.92^{\mathrm{a}}$ \\
212.50 & $48.04 \pm 1.38^{\mathrm{a}}$ & $43.53 \pm 2.01^{\mathrm{b}}$ & $40.80 \pm 2.28^{\mathrm{b}}$ \\
& & & \\
Cholesterol & & & \\
Control (0) & $45.07 \pm 1.26^{\mathrm{a}}$ & $41.82 \pm 2.28^{\mathrm{a}}$ & $40.91 \pm 1.28^{\mathrm{b}}$ \\
21.25 & $57.33 \pm 1.65^{\mathrm{c}}$ & $45.55 \pm 1.32^{\mathrm{a}}$ & $40.21 \pm 1.35^{\mathrm{ab}}$ \\
42.50 & $54.41 \pm 0.77^{\mathrm{bc}}$ & $58.11 \pm 3.92^{\mathrm{b}}$ & $37.12 \pm 0.40^{\mathrm{a}}$ \\
212.50 & $51.34 \pm 2.41^{\mathrm{b}}$ & $55.06 \pm 3.62^{\mathrm{b}}$ & $40.27 \pm 1.18^{\mathrm{ab}}$ \\
\hline \hline
\end{tabular}

Means with the same superscript letter(s) in a column are not significantly different in the DMRT test at $\mathrm{P}=0.05$.

\section{DISCUSSION}

The results obtained indicate that the $96 \mathrm{hLC}_{50}$ value of Faab and Morning fresh liquid soaps were found to be 0.062 and $0.085 \mathrm{ml} / \mathrm{L}$ respectively when tested on the guppy, P. reticulata. Analysis of Variance (ANOVA) showed that the quantal response of $P$. reticulata differs significantly $(p<0.05)$ among different concentrations at $24,48,72$ and $96 \mathrm{~h}$ of exposure to both toxicants. The results agreed with those of several authors (Anastácio et al., 2000; Morrall et al., 2003; Nalecz-Jawecki et al., 2003; Liwarska-Bizukojc et al., 2005) who observed that detergent products and their ingredients were relatively toxic to aquatic life. These results were also corroborated by Pettersson et al. (2000) who reported that anionic surfactants give toxic effects to various aquatic organisms at the concentrations from 0.0025 to $300 \mathrm{mg} / \mathrm{L}$.

On the basis of relative sensitivity of test species to Faab and Morning fresh liquid soaps, $P$. reticulata was more susceptible to FLS $\left(96 \mathrm{hLC}_{50}=0.062 \mathrm{ml} / \mathrm{L}\right)$ than to MFLS $\left(96 \mathrm{hLC}_{50}=0.085 \mathrm{ml} / \mathrm{L}\right)$. Based on derived $96 \mathrm{hLC}_{50}$, the computed toxicity factor (TF) revealed that FLS was slightly more toxic to $P$. reticulata than MFLS. The differential toxicity observed between test compounds; FLS and MFLS could be attributed to the difference in physical and chemical compositions of the surfactants. This observation is in consonance with investigations from other authors (Aguigwo, 2002; Otitoloju, 2005; Lawal \& Samuel, 2010) who reported that the level of toxicity of any toxicant depends on its 
bioaccumulation, the differential physical and chemical compositions of the compound forming the toxicant and the reaction of the exposed organism. The exposure of $P$. reticulata to FLS and MFLS resulted in exhibition of aggressive behavior, increased opercular movement and abnormal swimming movement. Similar behavioral responses were reported in $P$. reticulata exposed to chlorpyrifos-methyl (Mahmut et al., 2005) and pirimiphos-methyl (Lawal \& Samuel, 2010).

There was a decrease in the values of biochemical parameters; tissue protein, triglyceride, glucose and cholesterol in $P$. reticulata exposed to sub-lethal concentrations of surfactants with increased experimental days across treatments. This is in agreement with Joshi et al. (2002) that reported decrease in blood parameters of freshwater teleost fish Clarias batrachus after its exposure to lindane and malathione.

The progressive decrease in tissue protein observed in test organisms exposed to toxicants could be attributed to the utilization of protein in gluconeogenesis for the generation of glucose to overcome the stress posed by the toxicants (Omoniyi et al., 2002; Martinez et al., 2004). This result is corroborated by Wankede et al. (2000) who observed in the liver of fish, Channa orientalis a prominent protein decrease after exposure to lethal and sub-lethal concentrations of endosulfan and concluded that proteins were utilized in the production of energy to eradicate the pesticide stress. Maruthanayagam et al. (2000) also concluded that the decrease in total protein content in the kidney tissues of Channa punctatus fingerlings was due to the impact of detergent chemicals.

Triglyceride and cholesterol which are types of lipid found in blood and a source of energy, decreased progressively as the concentration of the toxicants increased. This may be due to the increased cellular activities resulted in metabolism of lipids to meet the increased physiological demand (Maruf Iftekhar et al., 2006; Abalaka et al., 2011) posed by the surfactants. Furthermore, lower level of triglyceride indicated the deficiency of hepatic metabolites compound as well as abnormal physiological function of the metabolism (Omitoyin, 2007). Similarly, progressive reduction observed in the tissue glucose value of $P$. reticulata exposed to sub-lethal concentration of surfactant, could be due to the impairment of the liver cells which consequently hinder gluconeogenesis. This result is in agreement with Ajani et al. (2007) who reported the decrease in plasma glucose concentrations after an initial increase to progressive depletion of energy due to the fact that the initial increased mobilization could not overcome the immediate threat of the toxicity.

The results obtained in this study showed that Faab and Morning Fresh liquid soaps are toxic on $P$. reticulata, therefore their indiscriminate discharge into drainage canals should be discouraged for healthy aquatic ecosystems particularly in an emerging economy.

\section{REFERENCES}

Abalaka, S.E.; Esievo, K.A.N. \& Shoyinka, S.V.O. 2011. Evaluation of biochemical changes in Clarias gariepinus adults exposed to aqueous and ethanolic extracts of Parkia biglobosa pods. African Journal of Biotechnology, 10(2): 234-240.

Aguigwo, J.N. 2002. The toxic effect of cymbush pesticide on growth and survival of African Catfish, Clarias gariepinus (Burchell, 1822). J. Aqua. Sci. 17(2): 81-84.

Ajani, F.; Olakunle, O.A. \& Agbede, S.A. 2007. Hormonal and haematological responses of Clarias gariepinus (Burchell, 1822) to nitrite toxicity. J. Fish. Int. 2(1): 48-53.

Anastácio, P.M.; Holten-Lützhøft, H.C.; HallingSørensen, B. \&. Marques, J.C. 2000. Surfactant (Genapol OX-80), toxicity to Selenastrum capricornutum. Chemosphere 40:835-838.

Barber, L.B.; Lee, K.E.; Swackhamer, D.L. \& Schoenfuss, H.L. 2007. Reproductive responses of male fathead minnows exposed to wastewater treatment plant effluent, effluent treated with XAD8 resin, and an environmentally relevant mixture of alkylphenol compounds. Aquat. Toxicol. 82(1):36-46.

Barbieri, E. 2007. The use of active metabolism and swimming activity to evaluate the toxicity of Dodecil Benzen Sodium Sulfonate (LAS-C12) on the Mugil platanus (mullet) according to the temperature and salinity. Water Environ. Res. 79(8): 707-719

Beey, A. 2001. What do sentinels stand for? Environ. Pollut. 112: 285- 298.

Cserha'ti, T.; Forga'cs, E. \& Oros, G. 2002. Biological activity and environmental impact of anionic surfactants. Environ. Int. 28:337-348.

Food and Agriculture Organisation (FAO). 1987. Manual of methods in aquatic environment research. Part 10 Short term static Bioassay. FAO Fish Tech Paper. 247. 62pp.

Finney, D.J. 1971. Probit Analysis, 3rd Edition, Cambridge University Press, Cambridge, UK. 318p.

Josephson, B. \& Gyllenswärd, C. 1957. The development of the protein fractions and of cholesterol concentration in the serum of normal infants and children. Scand. J. Clin. Lab. Invest. 9(1): $29-38$.

Joshi, P.K.; Bose, M. \& Harish, D. 2002. Changes in certain haematological parameters in a Siluroid 
catfish Clarias batrachus (Linn.) exposed to cadmium chloride. Pollut. Res. 21(2): 129-131.

Lawal, M.O. 2010. Bio-ecology of Poecilia reticulata (Peters, 1859) In Drainage Canal Systems of Lagos Metropolis, Nigeria. Ph.D. Thesis University of Lagos. 210p.

Lawal, M.O. \& Samuel, O.B. 2010. Investigation of Acute Toxicity of Pirimiphos-Methyl (Actellic®, $25 \% \mathrm{EC}$ ) on Guppy (Poecilia reticulata, Peters, 1859). Pakistan J. Biol. Sci. 13(8): 405 - 408.

Liwarska-Bizukojc, E.; Miksch, K.; Malachowska-Jutsz, A. \& Kalka, J. 2005. Acute toxicity and genotoxicity of five selected anionic and nonionic surfactants. Chemosphere, 58: 1249-1253.

Madsen, T.; Boyd, H.B.; Nylén, D.; Pedersen, A.R.; Petersen, G.I. \& Simonsen, F. 2001. Environmental and Health Assessment of Substances in Household Detergents and Cosmetic Detergent Products. Environmental Project no. 615.

Mahmut, S.; Rabia, S.; Figen, E. \& Oner, K. 2005. Investigation of acute toxicity of Chlorpyrifosmethyl on guppy Poecilia reticulata. Chemosphere, 60(1):93-96.

Martinez, C.B.R.; Nagae, M.Y.; Zaia, C.T.B.V. \& Zaia, D.A.M. 2004. Morphological and physiological acute effects of lead in the neotropical fish, Prochilodus lineatus. Braz. J. Biol. 64: 797-807.

Maruf Iftekhar, A.S.M.; Rayhan, I.; Quadir, M.A.; Akhteruzzaman, S. \& Hasnaf, A. 2006. Effects of Tamarindus indica fruits on blood pressure and lipid-profile in human model: An in vivo approach. Pak. J. Pharm. Sci. 19(2): 125-129.

Maruthanayagam, C.; Prema, R.; Shanthi, K. \& Sirajnisa, E. 2000. Impact of detergent on the biochemistry of the fresh water fish, Channa punctatus. Indian J. Environ. Ecoplan. 3(3): 637-642.

Morrall, D.D.; Belanger, S.E. \& Dunphy, J.C. 2003. Acute and chronic toxicity structure-activity relationships for alcohol ethoxylates. Ecotoxicol. Environ. Saf. 56: 381-389.

Nalecz-Jawecki, G.; Grabinska-Sota, E. \& Narkiewicz, P. 2003. The toxicity of cationic surfactants in four bioassays. Ecotoxicol. Environ. Saf. 54: 87-91.
Omitoyin, B.O. 2007. Plasma biochemistry changes in Clarias gariepinus (Burchell, 1822) fed poultry litter. Asian J. Anim. Sci. 1(1): 48-52.

Omoniyi, I.; Agbon, A. O. \& Sodunke, S.A. 2002. Effect of lethal and sublethal concentrations of Tobacco (Nicotiana tobaccum) leaf dust extract on weight and haematological changes in Clarias gariepinus (Burchell). J. Appl. Sci. Environ. Manage. 6(2): 37-41.

Otitoloju, A. A. 2005. Crude oil plus dispersant: Always a boon or bane? Ecotoxicol. Environ. Safety, 60 (2): 198-202.

Otitoloju, A. A. 2006. Joint action toxicity of spent lubrication oil and laundry detergent against Poecilia reticulata. Afr. J. Aquatic Science, 31: 125-129.

Pettersson, A.; Adamsson, M. \& Dave, G. 2000. Toxicity and detoxification of Swedish detergents and softener products. Chemosphere, 41:1611-1620.

Ross, L.G. \& Ross, B. 2008. Anaesthetic and Sedative Techniques for Aquatic Animals, 3rd Edition. WileyBlackwell, 240p.

Schettler, G. \& Nussei, E. 1975. Manahmen zur Prävention der Arteriosklerose. Arb Med. Soz. Med. Prav. Med.; 10: 25 - 29.

Teuscher, A. \& Richterich, P. 1971. New Swiss guide lines for the diagnosis of Diabetes mellitus. Schweiz Med. Wochenschr. 101(10): 345 - 352.

Wankede, V.W. \& Kulkarni, K.M. 2000. Liver protein profiles of the fish Channa orientalis exposed to endosulfan. J. Aqua. Biol. 15(1\&2): 89-91.

Zeni, C. \& Caligiuri, A. S. 1992. Morphological and ultrastructural changes induced by an anionic detergent on Ictalurus species barbel taste buds. Microbios. 69: 41-52.

Zeni, C.; Caligiuri, A. S. \& Bovolentab, M. R. 1995. Damage and recovery of Ictalurus species barbel taste buds exposed to sublethal concentrations of an anionic detergent. Aquatic Toxicology, 31(2): 113-123. 